\title{
Effect of Performance Appraisal System on Employee Productivity;(Selected Public Senior High Schools, Ho Municipality, Ghana)
}

\author{
Wright Evans Attipoe ${ }^{1} \quad$ George K. Agordzo ${ }^{2} \quad$ Mr. John E. Seddoh ${ }^{1}$ \\ 1.School of Graduate Studies University of Cape Coast, Cape Coast, Ghana \\ 2.School of Information and Electronic Engineering, \\ Zhejiang University of Science and Technology, Hangzhou, China
}

\begin{abstract}
Performance appraisals improve the work performance of employees by helping them realize their full potentials in carrying out their firm's mission and also, to provide information to employees and managers for use in making work-related decisions. They, also, provide feedback to employees and thereby serve as a vehicle for personal and career development. Performance appraisals, however, are beset with difficulties as a result of their complex nature. The general objective of the study, therefore, was to evaluate the performance appraisal system and its effect on employee productivity (performance) at the Ghana Education Service (GES). The research design used in the study was the descriptive study because it was appropriate for the achievement of the research objectives. The population for the study was 153 and a sample size of 108 respondents was selected using the probability and non-probability sampling method. Interview and questionnaires were used as instruments for the study and out of 106 questionnaires distributed, all of them were retrieved from respondents and interview conducted for two respondents. The data was analyzed with tables, bar charts. Among the main findings of the study was that the GES only carried out performance appraisal when teachers were due for promotion. The finding indicated a negative relationship between performance appraisal and productivity of teachers. It means that performance appraisal has no link with the WASSCE results. The study recommends that the Ghana Education Service should adopt performance apprnaisal that is tailored to the job description and the job analysis, that is, there should be a clear cut policy on the conduct of performance appraisal in the GES in order to improve on its conduct.
\end{abstract}

Keywords: High School, Productivity, Appraisal, Performance, Employee

DOI: $10.7176 / \mathrm{JESD} / 12-2-01$

Publication date: January $31^{\text {st }} 2021$

\subsection{Introduction}

The business environment has become very competitive due to uncertainty in labor markets and unpredictable employee behavior. Employers are now more than ever keen on employee recruitment, selection and placement and maintenance of performance standards in their companies.

Bateman and Snell, (1996), define performance appraisal as the process of assessing an employee's performance on a job for two basic human resource management (HRM) purposes, namely, administrative and developmental. For administrative purpose, performance appraisal provides information for future reference. The developmental purpose on the other hand provides that the information gathered be used to diagnose training needs and plan career for employees. Performance appraisal systems have been identified to offer a valuable opportunity to recognize employees' efforts and performance, detect key barriers and facilitators to work practices, identify professional development needs and opportunities. These benefits include; identification of an individual's strengths and weakness; identification of problems which may be restricting progress and causing inefficient work practices; development of a greater degree of consistency through regular feedback on performance and discussion about potential which encourages better performance from staff; improvement of the quality of working life by increasing mutual understanding of managers and their staff. There are various kinds of methods used for performance appraisal such as narratives, (essays - critical incidents), ranking comparisons (ranking method paired comparisons), checklists (simple - weighted), rating scales (graphic rating scales - behaviourally anchored rating scales (bars)) objective measures (goal setting standards (MBO)), 360-degree feedback. It appears however, that no single method is wholly efficacious, hence the need for a combination of methods, in order to make an objective appraisal of an employee on a balance of probabilities. In appraising the performance of employee teachers, there are some basic documents relied upon by the appraiser. These include lesson note book, log book, staff attendance book, movement book, pupils' attendance register, cumulative record books and student's exercise books among others.

In spite of the relatively good appraisal methods adopted by the GES, the practice over the years is that, appraisals are not conducted periodically and most often as should have been the case. Personnel of the service go through appraisals only when they are due for promotions. According to Alder and Coleman (2000), once-a-year job appraisals are typically not enough. They emphasize that effective job performance management must be an 
on-going process that is continuously monitored. Thus, for the effective evaluation of an employee, the personnel appraisal system must be at short intervals, with employees given feedback about how well or poorly they are performing. It has been observed that the employee is motivated when he/she sees improvement in his/her performance through positive remarks from colleagues. Productivity may be conceived of as a metric of the technical or engineering efficiency of production. To Bhatti \& Qureshi's (2007), perspectives, productivity is a performance measure encompassing both efficiency and effectiveness. With regard to Ghana Education Service (GES), productivity is explained in terms of how students passed the West African Senior Secondary Certificate Examination results.

\subsection{Motivation for the Study}

Performance appraisal (PA) has over the years become a very crucial part of the Human Resource Management (HRM) in organizations and its benefits to these organizations around the world cannot be overemphasized. To begin with, due to the lack of accountability and job security at the GES, most employees have a laissez faire attitude towards their work. There is also the unavailability of the job description for many employees (Fisk, 1995). As a result of this, employee performance has been greatly affected which has in turn affected the productivity and efficiency of the service. Again, there is a lot of laxity on the part of employees because they assume no measurement of performance is applied hence they work at their own pace (Daley, 1992). Figures from the School (OLA Girls' Senior High School) reveal that 79.8\%, 57.5\% and 79.3\% are the percentage of subjects failed(F9) in all the subjects for the year 2016, 2017 and 2018 respectively. This shows how dwindling the performance of the school is for the period mentioned (Abreh et. at., 2018). It is in view of the aforementioned that this study is designed to evaluate the performance appraisal system on employee productivity (performance) of the Ghana Education Service specifically among the teaching staff of Ola SHS and Shia SHTS in Ho Municipality. The specific objectives of the study were to; ascertain the various uses of performance appraisal schemes of Ola SHS and Shia SHTS in Ho Municipality, Assess the relationship between performance appraisal and productivity of teachers, to determine whether performance appraisal could be used as a tool to increase productivity of teachers in Ho Municipality.

\subsection{LITERATURE REVIEW}

\subsection{Performance Appraisal}

Armstrong (2006), describes the role of the performance appraisal as a tool for looking forward to what need to be done by people in the organization in order to achieve the purpose of the job to meet new challenges. According to Manasa \& Reddy (2009), Performance appraisal is a systematic and periodic process that assesses an individual employee's job performance and productivity in relation to certain pre-established criteria and organizational objectives. Performance appraisal has been defined as the process of identifying, evaluating, and developing the work performance of employees in the organization, so that the organizational goals and objectives are more effectively achieved, while at the same time benefiting employees in terms of recognition, receiving feedback, catering for work needs and offering career guidance (Lansbury, 1988).

According to Erdogan (2002), performance appraisal is the formal process of observing and evaluating employee's performance. According to DeNisi \& Pritchard (2006), 'performance appraisal' is a discrete, formal, organizational sanctioned event, usually not occurring more frequently than once or twice a year, which has clearly stated performance dimensions and/or criteria that are used in the evaluation process. Furthermore, it is an evaluation process, in that quantitative scores are often assigned based on the judged level of the employee's job performance on the dimensions or criteria used, and the scores are shared with the employee being evaluated. Furthermore, regarding definition of performance appraisal Grote (2002), stated that performance appraisal is a formal management system that provides for the evaluation of the quality of an individual's performance in an organization". Performance appraisal is "the process of evaluating how well employees perform their jobs when compared to a set of standards, and then communicating that information to those employees "(Mathis \& Jackson, 2000).

\subsection{Productivity}

Productivity is the balance between all production factors that will give the greatest return for the least effort (Drucker, 1974).Sink (1984), confines productivity to its simplest form Output/input. He states, "Productivity, as mentioned, is strictly a relationship between resources that come into an organizational system over a given period of time and outputs generated with those resources over the same period of time. It is most simply Output divided by Input." He also states that managers create confusion about productivity because they do not distinguish between productivity's definitions, measurement, and improvement on the one hand, and performance's concepts, measurement, and improvement, on the other. This failure to distinguish between productivity and performance can make communicating about productivity difficult. Bhatti \&Qureshi's (2007), perspectives, productivity is a performance measure encompassing both efficiency and effectiveness. 


\subsection{Performance Appraisal Process}

Performance Appraisal is planned, developed and implemented through a series of steps as illustrated by Aquinas (2009).

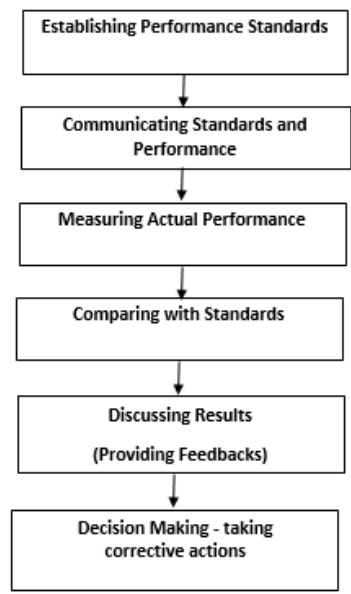

Source: Aquinas (2009)

Figure 1: Process of Performance Appraisal

The first step in the process of performance appraisal is the setting up of the standards which will be used as the base to compare the actual performance of the employees. This step requires setting the criteria to judge the performance of the employees as successful or unsuccessful and the degrees of their contribution to the organizational goals and objectives. The standards set should be clear, easily understandable and in measurable terms. In case the performance of the employee cannot be measured, great care should be taken to describe the standards (Aquinas, 2009). Once set, it is the responsibility of the management to communicate the standards to all the employees of the organization. The employees should be informed and the standards should be clearly explained to them. This will help them to understand their roles and to know what exactly is expected from them. The standards should also be communicated to the appraisers or the evaluators and if required, the standards can also be modified at this stage itself according to the relevant feedback from the employees or the evaluators (Aquinas, 2009).

The most difficult part of the Performance appraisal process is measuring the actual performance of the employee's, that is the work done by the employees during the specified period of time. It is a continuous process which involves monitoring the performance throughout the year. This stage requires the careful selection of the appropriate techniques of measurement, taking care that personal bias does not affect the outcome of the process and providing assistance rather than interfering in an employees work (Aquinas, 2009). The last step of the process is to take decisions which can be taken either to improve the performance of the employees, take the required corrective actions, or the related HR decisions like rewards, promotions, demotions, transfers etc. In summary, the above are the steps illustrated by Aquinas (2009), in carrying out a successful performance appraisal in an organization.

\subsection{Linking Performance Appraisal to Productivity}

The Productivity of any organization is directly correlated to the Effectiveness of the Employee Performance Appraisal. Performance appraisal if properly done is believed to contribute greatly to the efficiency of the entire organization, as it ensures continuous improvement on areas identified as crucial for employing a positive and reinforcing management system, Khazem (2008). For the efficient management and evaluation of employees, performance appraisal is needed. It helps employees to develop, facilitate organizational progress in terms of performance. Business planning often makes use of appraisals. The system hinges on the size and structure of the company or the organization. This allows management to examine the standards; establish expectations, goals and objectives; and hand over tasks and obligations (Walsh \& Fisher, 2005). Moreover, since the communication within the organization improves as an effect of performance appraisal, employees tend to be more committed, satisfied and improve their output (Wiese \& Buckley, 1998). According to Walsh and Fisher (2005), Training needs are determined through such system and could help in the conduct of training needs analysis for the productivity of an organization.

Finally, it serves as records of the performance of employees and could help in future development plans. Job performance appraisals - in whatever form they take - are vital for managing the performance of the people and organization. A simple recognition of an individual as embodied in the performance appraisal can give way to increased job satisfaction and could help trim down turnover and absenteeism rates thereby improving the 
productivity of an organization. In conclusion, Khazem (2008), identify the importance of performance appraisal of employees on the outcome (productivity) and its impact on management system. So once the organization has an effective appraisal system it helps employees to develop, facilitate organizational progress in terms of performance; once there is an efficient management system, it is assumed that the productivity of the organization will not be compromised due to the efficient performance appraisal system.

\subsection{Corporate Productivity and Performance Assessment System}

Prasetya and Masanori (2010), stressed that in a highly competitive era of globalization, companies need high performance. In any profit-oriented or non-profit-oriented organizations, human resources have an important role in achieving organizational efficiency and effectiveness by managing the physical, financial and human resources in the most effective and efficient way; by developing a variety of complex processes and procedures. Among others, the most important dimensions of managing human resources are the assessment of performance (also known as performance evaluation, performance appraisal, performance management, reviews or ratings) and the implementation of a good salary system. At the same time, employees need feedback about their performance and guidance for their future behaviour.

Every organization can attain its set goals and objectives through the increase of productivity. Higher productivity increases efficiency in the organization's operations, while the level of productivity itself is highly influenced by the performance or productivity of the employees. One of the important factors affecting employee productivity is motivation. Work motivation can generate enthusiasm and drive to work. Motivation can come from both internal and external sides. Externally, it can be obtained from the organization. In this regards, managers have duty to create a work environment that is conducive to developing motivation (Prasetya \& Masanori, 2010). Productivity can be defined as the ratio of output to input. Work productivity is affected by motivation, where the higher motivated employee will tend to be more productive, and vice versa. Silberman (2003), noted that "an effective performance management program can increase productivity and morale in your organization and help you retain valued high-performers". Meanwhile, according to Bruce (2002), the way to increase employees ${ }^{\text {ee }}$ motivation and productivity is by ensuring everyone to have a common understanding of what high performance is and by ensuring that employees know what is expected from them. Furthermore, she suggested that managers should recognize that they have influence to the employees and should use this influence to convince them that motivation has positive relation with performance. To improve company's performance, the company should implement a good performance appraisal and salary systems to enhance employees' motivation.

\subsection{Theories of Performance Appraisal}

\subsubsection{Goal Setting Theory}

Edwin Locke (1960), put forward the Goal-setting theory of motivation. This theory states that goal setting is essentially linked to task performance. It states that specific and challenging goals along with appropriate feedback contribute to higher and better task performance. In simple words, goals indicate and give direction to an employee about what needs to be done and how much efforts are required to be put in. One dimension focuses on the raterratee relationship comprising topics such as supervisor support, trust, rating accuracy, and reliability as a precondition for the acceptance and usefulness of formal appraisal systems.

Goal setting is not without its critics. Ordóñez, Schweitzer, Galinsky, and Bazerman (2009), stated that the theory is over-prescribed and can potentially cause harm to an organization. Care should be taken in applying goal setting due to the possible unintended side effects. The arguments levied against the theory are not new and have been discussed by previous researchers. For example, Ordóñez, et al. (2009), argued that unethical behavior can result from motivating employees to meet specific and challenging goals. In an effort to reach a sales quota, salespeople may either fudge numbers or lie to customers in order to reach their monetary goal. According to the authors, this focus on goal attainment can actually promote unethical behavior by creating a "focus on ends rather than the means" (Ordóñez, et al., 2009, p. 12). Not only was negative behavior addressed by Latham and Locke, but the means to mitigate this issue were offered as well, such as offering progressive awards toward goal attainment, organizational control systems, and an ethical workplace culture (O'Neil \& Drillings, 1994).

The preponderance of empirical research supporting goal-setting theory illustrates its utility as a method to motivate individuals and improve organizational outcomes. While some caution may be in order, Locke and Latham (2002), argue that failures resulting from the theory are usually due to errors in its application and can often be prevented. The subject of human motivation is vast and complex. No single theory fully explains every aspect of what motivates individuals to perform better. According to Locke and Latham (2002), using techniques such as co-relational, experimental and quasi-experimental design, a plethora of research studies have been conducted over 40 years using close to 40,000 participants in eight countries, over time periods varying from one minute to 25 years. Smith \& Hitt (2005), in their book, Great Minds in Management, reinforced the popularity of this theory with their reference to a 2003 assessment of OB scholars who rated goal-setting theory first in importance out of seventy-three management theories, validating the claim that goal setting has had tremendous 
research and practitioner support.

Goal setting creates an alternative purpose for work and provides the challenge that enables individuals to overcome even the most physically exhausting tasks. From a psychological standpoint, a sense of pride develops from an individual's improved self-interest; which may lead to better jobs and increased pay overtime. When making the commitment to set a goal and focus on its accomplishment within a specified period of time, attention is often diverted away from activities that are considered goal-irrelevant. For this reason, people are often motivated to utilize or discover the knowledge necessary for successful completion (Latham, 2004).

2.6.2 Expectancy Theory

Expectancy theory which was developed by Victor Vroom (1964), states that motivation is the function of an individual's expectancy that effort will lead to performance, instrumentality judgment that performance will lead to certain outcome, and valence of outcomes (Miyamoto, 2007). The strength of expectancy theory is that it is practical, simple, easy to apply and most important is that the theory works (Quick, 1988). Quick (1988), also stated that human behaviour, expectancy theory explains, is a function of two factors which is the perceived value of the reward that certain behavior yield and the expectation in the doer that certain behavior actually yield that reward. Expectancy theory can be translated into five simple steps that can help managers motivate their employees. The five steps include define the expectation, make the work valuable, make the work doable, give regular feedback and reward employees when they meet the expectation. In fact, manager would find these steps very helpful and that manager who practices and follows these steps would be able to motivate the employees.

The weakness of expectancy theories is that the relationship between effort and performance will not be perfect since it is moderated by one's skills and knowledge and by the difficulty of the task (Ferris, Beehr \& Gilmore, 1978). Employees' skills and knowledge play an important role as more skillful and more knowledgeable employees will find it easier to complete the job. However, the difficulty of the job can only be determine by the employees himself or herself, because each of the employees have different level of skills and knowledge and that the manager cannot assume that the job which are easy for a particular employee are also easy for the other employees. The advantage of Expectancy theory is that it provides a framework for understanding how motivation operates in a given situation. The weakness of the expectancy theories again is that the specification of an outcome from some choice of job behavior is more complex and open ended (Connolly, 1976). Manager might assume that giving several positive outcomes is enough to motivate their employees; however, this may be wrong because one outcome may lead to another in an extended sequence. For example, choosing to work hard may be associated to increase in wages; however this does not stop there because demand for the employees will increase from time to time. Managers might find it hard to cope to employees demand as their demand might change or remain, and the only way to know is through two way communication or having feedback form from time to time. One of the drawbacks of expectancy theory in my view is that perceptions about effort, performance and the value of rewards are difficult to quantify so comparisons between different choices or people using the expectancy theory framework may not be accurate so, people will be using the theory wrongly. Expectancy theory implies that individuals will only use effort toward something for a reward. This implication seems to conflict with altruism, which describes actions done purely to benefit others without regard for personal rewards. What it means from the view of the researcher is that people will not work unless there is awaiting rewards for them before they can work hence laziness will become the order of the day leading to low performance. In addition, rewards may not necessarily be directly connected to effort and performance; it means that specific job skills, educations that are necessary might not be there. When these things (provision of education, training) managers will become an employee champion and change agent in the organization rather than making them lazy.

2.6.3 Empirical Review

Pettijohn et al. (2001), undertook a study to examine the attitudes of nearly 32,000 American federal employees toward performance appraisal. A descriptive survey design was used for the study. Both questionnaire and interview guide were used in eliciting data from the respondents. Pettijohn et al. (2001), concluded that the employees were dissatisfied with the way performance appraisal was conducted and that less than one-fifth felt that the process motivated employees to perform well. They however, claimed that there is no empirical evidence that performance appraisal itself is undesirable. This is because from their study almost half (46 percent) liked the concept of the process as it gave them an indication of where they ranked among co-workers.

Simmons (2002), undertook a study to examine the views of experts on performance appraisal in universities and colleges. He used the stratified random sampling procedure to select both appraisers and appraise from 430 elements. Simmons' study found that employees viewed the PA process as beneficial. Managers and professionals also found the process as having overall value, with very few suggesting it should be discarded altogether. However, problems identified from Simmons' study included patchy application, uneven managerial commitment, lack of continuity between appraisal, the link with performance related pay and teamwork, and the appropriateness of individual performance review for lower-graded staff merit further attention. But there was a general negative perception of the effects of the link between individual performance review and pay. Mani (2002), also found from her study at the East Carolina University that many employees are motivated by factors that 
do not relate to the performance appraisal system ( PAS). According to her, many are self-motivated or motivated by the enjoyment of their work, and pay, an extrinsic reward, ranked third among the things that motivated these employees. However, she warned that this self-motivation and enjoyment of work will cease if employees' pay is not adequately increased, as increases in pay was also seen as a symbol of recognition. From the point of view of researcher, the propounders did not take into account the means through which these goals can be achieved because goals are set to be achieved, so it is relevant to look at the variables that may lead to achieving those goals. To be competitive in the competitive business environment, firms must be proactive in development of human capital which will help them to achieve quality work that will lead to the attainment of the required goals. So, investing in the human beings is ignored from their explanation of the goal setting theory. In the nutshell, goal setting theory does not take into account the 'How' nature of goals into consideration (investing in the human beings to help them accomplish a goal).

\subsection{Conceptual Framework}

The model below explains how skills, attitude, and knowledge can influence performance appraisal of an organization and in turn influence the performance (productivity) of its employees. The model below shows arrows from the factors that can influence performance appraisal of an organization. Performance appraisal also shows an arrow indicating how it is influencing the performance of its employees.

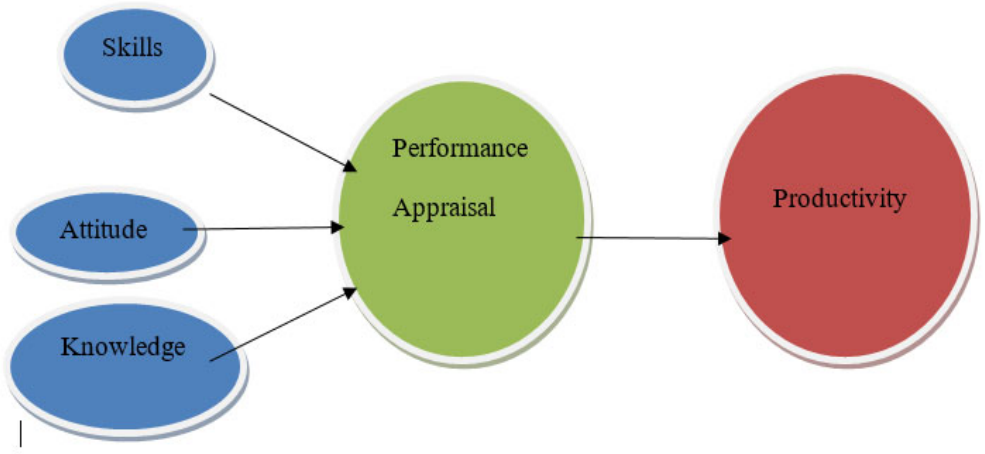

Source: Author's Construct (2019)

Figure 2: Model showing the Effect of Performance Appraisal on Productivity.

Skill: "The notion of "skill" has been one of the most elusive and hardest to-define concepts in labor economics" (Lafer, 2002). In many studies skills and skill levels are defined as some combination of education, training and experience Pro Inno Europe, 2007). Skills development" is understood in broad terms, concerning human resources training and development. "It is the task of basic education to ensure to each individual the full development of the human personality; and to lay the foundation for employability. Initial training develops further his or her employability by providing general core work skills, and the underpinning knowledge, and industrybased and professional competencies which are portable and facilitate the transition into the world of work. Lifelong learning ensures that the individual's skills and competencies are maintained and improved as work, technology and skill requirements change; ensures the personal and career development of workers; results in increases in aggregate productivity and income; and improves social equity." Weber et al (2013), finds that high skills have a positive effect on productivity, whilst low skills tend to have a negative effect. It is realized that skills have a vital role to play in productivity every organization being it public or private sector. Once employees are well equipped with the necessary skills for the job, they will be able to deliver.

Attitude: An attitude is an expression of favor or disfavor toward a person, place, thing, or event, Gordon (1967). Attitude is a disposition or state of mind. Positive attitude manifest in the following ways; positive thinking, constructive thinking, motivation and energy to do things and accomplished goals. What it means is that, the behavior that the person brings to work can affect productivity. In measuring attitude, we can look at how creative; innovative the person is in carrying out the duties. Once all these things are identified and work on will reflect on the person's output.

Knowledge: In an organizational context, knowledge is the sum of what is known and resides in the intelligence and the competence of people. Andre (2013), explained knowledge to be "Things that are held to be true in a given context and that drive us to action if there were no impediments". Sweiby (1986), explained knowledge as a "Capacity to act" and he explained capacity as "Justified true belief that increases an entity's capacity for effective action" (Nonaka \& Takeuchi, 2011). "The perception of the agreement or disagreement of two ideas"

Performance Appraisal: Performance appraisal is a systematic process that seeks to evaluate employees' performance and helps in identifying employee's potential for further growth and advancement within the Organization's career ladder (Shamaila Burney, 2012). Armstrong (2006), describe the role of the performance 
appraisal as a tool for looking forward to what need to be done by people in the organization in order to achieve the purpose of the job to meet new challenges.

Productivity: "Productivity is a relationship between outputs and inputs. It raises when an increase in output occurs with a less than proportionate increase in inputs, or when the same output is produced with fewer inputs" (ILO, 2005). A low-wage, low-skill development strategy is unsustainable in the long term and incompatible with poverty reduction. Investment in education and skills helps to "pivot" an economy towards higher value added activities and dynamic growth sectors.

\subsection{METHODOLOGY}

\subsection{E Study Area and Research Design}

The study area for this study is the Ho municipality in the Volta Region of Ghana. The Ho Municipal is one of the 254 Metropolitan, Municipal and District Assemblies (MMDAs) in Ghana. The Municipality is also the Administrative capital of the People of the Volta Region from which Oti region was curved in 2019.

This work employed the descriptive research design for the study. Descriptive research is a research that specifies the nature of a given phenomenon. It determines and reports the way things are. According to Best and Khan (1998), descriptive research is concerned with the conditions or relationships that exist, such as determining the nature of prevailing conditions, practices and attitudes; opinions that are held; processes that are going on; or trends that are developed. Descriptive research deals with interpreting the relationship among variables and describing their relationships. The purpose of employing descriptive research was to enable the researcher to observe, describe, and document the role that performance appraisals play with respect to students' performance in their West African Senior Secondary Certificate Examination result (productivity). The researcher adopted mixed method (both quantitative and qualitative) approach for the study.

\subsection{Data Collection Procedures}

First, a letter was sent to the management//heads of these schools to grant the researcher permission to administer questionnaire and conduct interviews in their institution. Three types of questionnaires were administered to two types of respondents: heads and teachers. Questionnaires for teachers were self-administered. In the first method, the Headmasters/Mistress spoke to their staff and then requested them to fill the questionnaires. In the second method, the questionnaire was numbered, distributed to the staff. Due to the nature of the work of Headmasters/Mistress, the researcher collected the information through personal interview. Additionally, two assistant headmasters took part in telephone interview where they provided in-depth information on how performance appraisal can result into productivity.

\subsection{Data Processing and Analysis}

Data was analyzed using SPSS and Microsoft Excel to achieve objectives one, to ascertain the various uses of performance appraisal. The SPSS version 16 was used to perform statistical analysis while Microsoft Excel was used to present various charts to give a good pictorial interpretation of the analysis because of the image clarity. The relevant information was retrieved in a standard form using tables, figures, frequencies and percentages, graphs for analysis and interpretation of the information. The reason for the choice of analysis method was because the study collected quantitative data. In order to analyze the data of this study using quantitative analysis, the researcher used both descriptive and inferential statistics. The reason for using descriptive statistics was because the researcher wanted to summarize the data collected in tables, figures, frequencies and percentages, graphs for better understanding for the readers and for us to easily examine the results. An interview was conducted on this particular objective to assess how Performance Appraisal can be best used as an effective tool for improving the output of teachers in Ghana Education Service (G.E.S). Questions were asked to arrive at the answer for the objective.

\subsection{RESULTS AND DISCUSSIONS}

4.1 Use of Performance Appraisals

Over the years, performance appraisals have always been used as a form of evaluating the output of an individual measured against certain expectations. The table below presents Likert scale response by teachers on the uses of performance appraisal to evaluate their performance pertaining to some identified variables. 
Table 4.2 Respondents Perception on uses of Performance Appraisal

\begin{tabular}{|c|c|c|c|c|c|c|c|c|c|c|}
\hline \multirow[t]{2}{*}{ Statement } & \multicolumn{2}{|c|}{$\begin{array}{l}\text { Strongly } \\
\text { Disagree }\end{array}$} & \multicolumn{2}{|c|}{ Disagree } & \multicolumn{2}{|c|}{ Neutral } & \multicolumn{2}{|c|}{ Agree } & \multicolumn{2}{|c|}{ Strongly Agree } \\
\hline & Percent & Freq- & Percent & Freq- & Percent & Freq- & Percent & Freq. & Percent & Freq- \\
\hline $\begin{array}{l}\text { My promotion at } \\
\text { work is based on } \\
\text { how well my } \\
\text { students perform } \\
\text { in their WASSCE } \\
\text { results }\end{array}$ & 54.7 & 58 & 31.1 & 33 & 5.7 & 6 & 6.6 & 7 & 1.9 & 2 \\
\hline $\begin{array}{l}\text { My promotion is } \\
\text { as a result of } \\
\text { recommendations } \\
\text { given by my } \\
\text { superior }\end{array}$ & 16.0 & 17 & 49.1 & 52 & 1.9 & 2 & 26.4 & 28 & 6.6 & 7 \\
\hline $\begin{array}{l}\text { I am promoted } \\
\text { based on the } \\
\text { number of years I } \\
\text { served in the } \\
\text { service }\end{array}$ & 1.9 & 2 & 2.8 & 3 & 1.9 & 2 & 13.2 & 14 & 80.2 & 85 \\
\hline $\begin{array}{l}\text { My compensation } \\
\text { is based on } \\
\text { performance } \\
\text { appraisal }\end{array}$ & 88.7 & 94 & 4.7 & 5 & 1.9 & 2 & 4.7 & 5 & 0.0 & 0 \\
\hline
\end{tabular}

The purpose of this session of the research was to find out the uses of performance appraisal system within the GES as such, the variables explored helped unravel how performance appraisal system is used in the service. From table 4.2 above, more than half of respondents (58) representing $54.7 \%$ strongly disagreed to the fact that their promotion at work is based on how well students performed in their WASSCE results with only 7 respondents representing $6.6 \%$ agreeing to this notion. With regards to teacher's promotion being a result of recommendation by their supervisors, 17 respondents signifying 16.0 and 52 respondents representing 49.1 showed different levels of disagreement; while 28 respondents signifying 26.4 were in agreement, only 2 respondents (1.9) were neutral in their response. Again from table above, while combined $4.7 \%$ representing 5 respondents were in disagreement with their promotion dependent on the number of years served in the education service, more than half of respondents 85 representing $80.2 \%$ strongly agreed to been promoted based on number of years served. Finally, from the table, more than $90 \%$ of respondents disagreed to been compensated as a resulted of performance appraisal.

Armstrong (2006) findings contradict the result found. Armstrong (2006), describes the role of the performance appraisal as a tool for looking forward to what needs to be done by people in the organization in order to achieve the purpose of the job to meet new challenges. A well-structured performance appraisal system must stimulate employee enthusiasm and creativity. The question then now is whether or not the service does not care about output as indicated $88.7 \%$ of the respondents strongly disagreeing that their promotion was based on their students' WASSCE results.

In spite of the relatively good appraisal methods adopted by the GES, the practice over the years was that, appraisals were not conducted periodically and most often as should have been the case. Personnel of the service were appraised only when they were due for promotions. They emphasize that through positive remarks from colleagues, effective job performance management must be an on-going process that is continuously monitored. Thus, for the effective evaluation they are performing. It has been observed that the employee is motivated when he/she sees improvement in his/her performance of an employee, the Personnel Appraisal system must be at short intervals, with employees given feedback about how well or poorly.

According to Lansbury (1988), Performance appraisal has been defined as the process of identifying, evaluating, and developing the work performance of employees in the organization, so that the organizational goals and objectives are more effectively achieved, while at the same time benefiting employees in terms of recognition, receiving feedback, catering for work needs and offering career guidance. From Lansbury view point, when employees are satisfied they will be able to work to achieve organizations' goals. Now we realized that $75 \%$ of the respondents said they were promoted based on the number of years served as compared to a high number of respondents saying that their promotion did not depend on their output. What it means is that there is no correlation between output and performance appraisal hence employees will not be motivated and satisfied to work harder.

\subsection{Comparison of Schools on Uses of Performance Appraisal}

Table 4.2 above presented the aggregated response of the respondents (teachers) from the two schools selected for the research on their perception on the use of performance appraisal to evaluate their performance. Figure 4.1 below shows a comparison of the responses from teachers from these two schools on how they perceive the use of performance appraisal to evaluate their performance on some indicators specified by the researcher. 


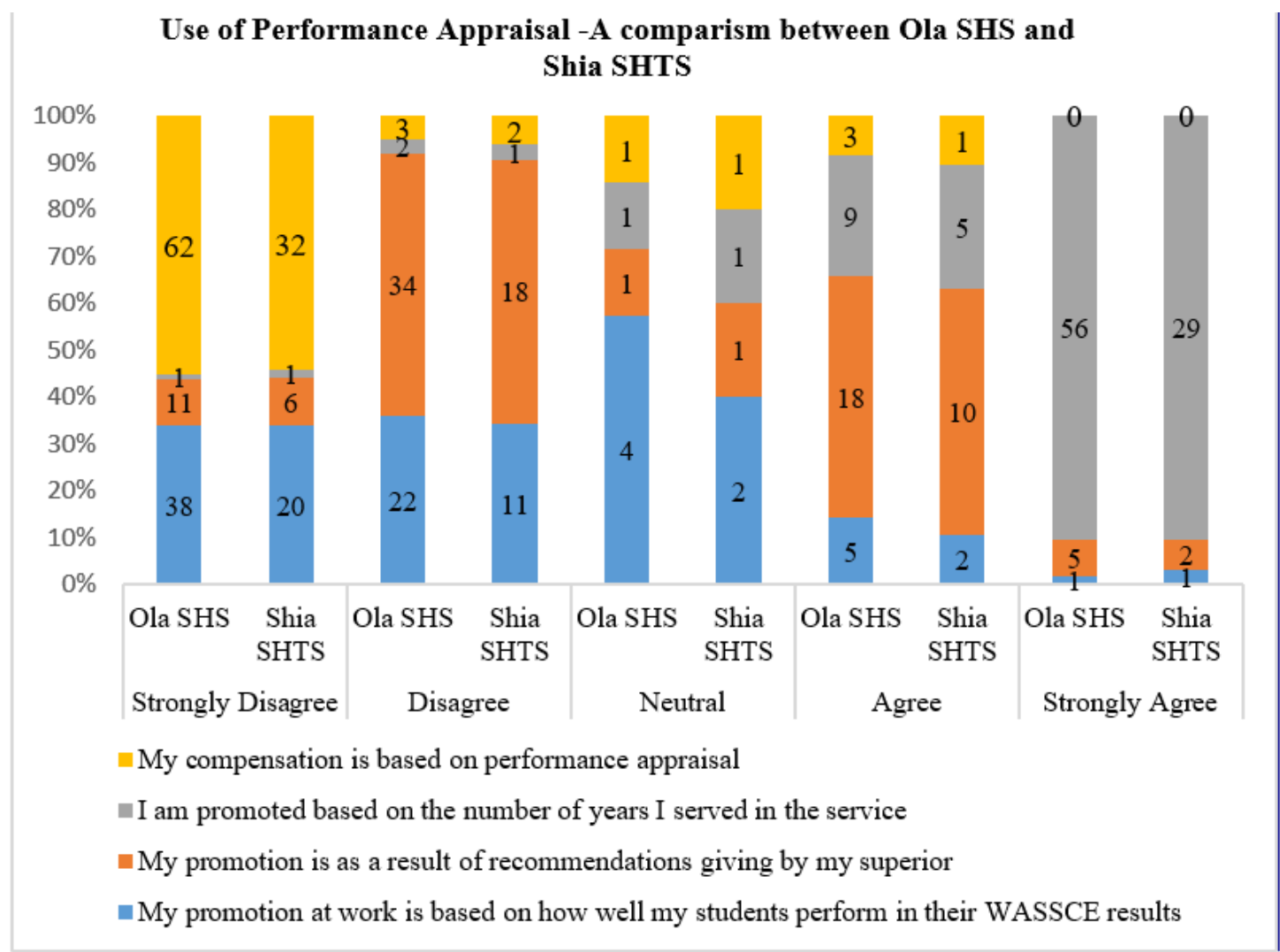

Source: Authors Field Survey, (2019)

Figure 1: Comparison of Schools on uses of Performance Appraisal

It is indicated from figure 1 above that of the 70 respondents from Ola senior high school (Ola SHS), 62 and 3 of them strongly disagreed and disagreed respectively to their compensation based on their performance appraisal with only 3 of them in agreement. The outcome was not different in Shia senior high technical school (Shia SHTS) where 32 out of 36 respondents strongly disagreed with their compensation dependent on performance appraisal. Again on the average, outcome of findings regarding teachers' promotion at work based on students' performance in WASSCE was in the negative as 60 out of 70 teachers from Ola SHS and 31 out of 36 teachers from Shia SHTS showed different levels of disagreement. Only 5 and 2 teachers agreed to this notion from Ola SHS and Shia SHTS respectively. From figure 4.1, responses from teachers in both schools were skewed in affirmative with regards to been promoted based on the number of years served as 65 out of 70 teachers and 34 out of 36 teachers from Ola SHS and Shia SHTS showed different levels of agreement.

From the work Walsh and Fisher (2005), they indicated that the education outcome of students is a combined obligation of teachers, parents and the students themselves as well as other external factors which act upon their performance hence positive and negative outcomes of students are shared responsibility of all parties involved and not a single actor. The findings of Walsh and Fisher (2005) thus confirm a finding from this study where teachers disagreed to their promotion being dependent on the performance of students in their final exams (WASSCE).

\subsection{Relationship between Performance Appraisal and Productivity of Teachers}

According to Khazem (2008), the objective of staff appraisal is to improve planning and service delivery at the general level and also to provide feedback to individual officers. Thus performance appraisal provides information to help manage employees in such a way that employee performance improves. According to him, the ultimate goal of most performance appraisal systems is to increase employee motivation and productivity. The study thus gathered replies from respondents on some key variable that can be used to measure the relationship between performance appraisal and their productivity. Responses for variables measured are displayed below. 
Table 3: Steps are taken to deal with poor performance of Teachers in my School

\begin{tabular}{lll}
\hline Responses & Frequency & Percent \\
\hline Strongly Disagree & 41 & 38.6 \\
Disagree & 36 & 34 \\
Neutral & 6 & 5.7 \\
Agree & 18 & 17 \\
Strongly Agree & 5 & 4.7 \\
\hline Total & 106 & 100 \\
\hline & \multicolumn{2}{|c|}{ Source: Authors Field Survey, (2019) }
\end{tabular}

From table 4.3, 41 teachers representing $38.6 \%$ and 36 additional teachers representing $34 \%$ showed different intensities of disagreement to the view of steps taken to deal with poor performance of teachers in their respective schools. Also from the table, while 18 teachers representing 17\% and 5 additional teachers representing $4.7 \%$ showed different intensities of agreement, only 6 teachers representing 5.7\% were neutral in their response against the idea of steps taken by supervisors to deal with poor performance of teachers in their schools.

Findings from this study endorse similar findings from (Joison, 2001) who indicated that performance appraisals are often linked to incentives such as raises and promotion for a worker whose performance is reviewed as high, and possible job cuts for a worker whose performance is reviewed as low. As such, supervisors or evaluators in the spirit of togetherness and solidarity are likely to overlook some poor performance of employees and may only take action on such an employee covert to the entire organization. Joison, 2001, however suggested that, this should not be the case since a well-designed performance appraisal system should develop criteria for successful performance, give performance feedback and enable a more equitable reward system. To him performance appraisal forms the basis of evaluating the employees' performance and their contribution towards the organization goal as it consists of the desired outputs expected of employees hence performance appraisal approaches should be aligned with goals, relevant to given roles, specific and measurable, under employees control and understood and accepted by participants.

Table 4: In my School, Steps are taken to deal with Poor Performance of Teachers who cannot or will not improve on WASSCE Results

\begin{tabular}{lll}
\hline Responses & Frequency & Percent \\
\hline Strongly Disagree & 30 & 28.3 \\
Disagree & 33 & 31.1 \\
Neutral & 21 & 19.8 \\
Agree & 18 & 17 \\
Strongly Agree & 4 & 3.8 \\
\hline Total & $\mathbf{1 0 6}$ & $\mathbf{1 0 0}$ \\
\hline & & Source: Authors Field Survey, (2019)
\end{tabular}

From the table, more than half of respondents thus 30 representing $28.3 \%$ and 33 representing $31.1 \%$ indicated diverse intensity of disagreement to the perception of steps been taken to deal with poor performance of teachers who cannot or will not improve on WASSCE results of their students. Nonetheless while 18 respondents representing $17 \%$ and 4 extra respondents signifying $3.8 \%$ agreed, a good number of respondents (21) representative of $19.8 \%$ were neutral in their response to steps taken to deal with poor teacher performance concerning WASSCE results.

Again discoveries from Walsh and Fisher (2005) support this finding where they indicated that, the education outcome of students is a combined obligation of teachers, parents and the students themselves as well as other external factors which act upon their performance hence positive and negative outcomes of students are shared responsibility of all parties involved and not a single actor. Also, they suggested school actions taken against poor performance of students is not exemplary but rather should include parents and guardians whom should be concerned about their children's academic performance, showing dedication in their children's learning through availing themselves during parents' meetings, in order to gain a better understanding of the performance of their children. 
Table 5: Teacher's Performance Appraisal is a fair Reflection of Students WASSCE Results

\begin{tabular}{lll}
\hline Responses & Frequency & Percent \\
\hline Strongly Disagree & 68 & 64.1 \\
Disagree & 16 & 15.1 \\
Neutral & 1 & 0.9 \\
Agree & 14 & 13.1 \\
Strongly Agree & 6 & 5.7 \\
\hline Total & 106 & 100 \\
\hline & & Source: Authors Field Survey, (2019)
\end{tabular}

From table 4.5 above, more than half of respondents thus 68 representing $64.1 \%$ and 16 representing $15.1 \%$ indicated diverse intensity of disagreement to the perception of teachers' performance appraisal been a fair reflection of students WASSCE results. Nonetheless while 14 respondents representing $13.1 \%$ and 6 extra respondents signifying 5.7\% agreed, only 1 respondent (0.9) was neutral to this accession. According to Anlimachie (2012) in his study on the poor performance of Ghanaian students in WASSCE indicated that, student poor performance in the exams is attributed to structural deficiencies in the practicability of subjects studied in school, the lack of instructional materials or resources centers; insufficient quality teachers; insufficient support to the teaching and learning of the discipline by the stakeholders; less fieldwork activity in lessons and the apathy of students to the teaching and learning of subjects of their interests while better outcomes suggest the opposite. His findings support the major outcome of this finding where student performance to greater extent is independent of teachers' performance appraisal.

\subsection{Interview Response on how Performance Appraisal can result into Productivity}

In the researcher's quest to find out the extent to which performance appraisal can used to as a tool to increase productivity of teachers of Ghana Education Service in the Ho municipality, the assistant headmasters of the Ola SHS and Shia SHTS were interviewed.

According to one of them, "I belief all the elements under the core competencies of performance appraisal must be measured to know if that were the true reflection of the teacher". The respondent additionally stated that, supervisors must carry individual teacher performance appraisal form to the schools to see if the percentage attached to the ratings merit that teacher as this is the only way to see performance appraisal as a tool to boost performance. The respondent further explained the need to engage medical practitioners in supervision to help identify teachers with mental problems to compliment the work of special education officers by way of enhancing productivity of teachers.

According to another respondent in the areas of decision making, "an all-inclusive style to decision making is needed so that all teachers can be part of all activities that go on in the school including how to use capitation grant". The respondent stated that, even though work inspection was good, supervisors must be firm, fair and give a true picture of teacher's performance and submit a result devoid of favoritism as the respondent was of the view that some supervisors were being bias in doing their work which brings about untruthfulness in the appraisal system. According to another respondent, "I think there is the need for periodic training after appraisal of teachers to bridge the gap identified based on the appraisal record". It is seen from the responses that performance appraisal can best be improved upon in the atmosphere of strict supervision on the part of the managers. This was confirmed by McGregor's Theory X which postulates that the average person is lazy and has an inherent dislike for work and as a result, people must be coerced, controlled, directed and threatened with punishment if the organization is to achieve its objectives, (Mullins, 2002).

\subsection{Correlation between Performance Appraisal and Productivity of Teachers}

In order to establish if there is a mutual relationship or connection between performance appraisal and productivity of teachers, two variables were selected to test for the relationship. For performance appraisal; my compensation is based on performance appraisal was selected while for productivity of teachers, teacher's performance appraisal is a fair reflection of students WASSCE results was selected. According to Pearson correlation coefficient, a value of exactly 1.0 means there is a perfect positive relationship between the two variables thus for a positive increase in one variable, there is also a positive increase in the second variable. A value of -1.0 means there is a perfect negative relationship between the two variables thus for a positive increase in one variable, there is a decrease in the second variable. If the correlation between two variables is 0 , there is no linear relationship between them. The correlation between the variables is depicted in the table below. 
Table 6: Correlation between Performance Appraisal and Teacher Productivity

\begin{tabular}{|c|c|c|c|}
\hline & & $\begin{array}{l}\text { Performance Appraisal } \\
\text { (My compensation is } \\
\text { based on performance } \\
\text { appraisal). }\end{array}$ & $\begin{array}{l}\text { Productivity of } \\
\text { teachers (Teacher's } \\
\text { performance } \\
\text { appraisal is a fair } \\
\text { reflection of } \\
\text { students WASSCE } \\
\text { results). }\end{array}$ \\
\hline \multirow{3}{*}{$\begin{array}{l}\text { Performance Appraisal (My } \\
\text { compensation is based on } \\
\text { performance appraisal). }\end{array}$} & Pearson Correlation & 1 & $.437^{* *}$ \\
\hline & Sig. (2-tailed) & & .000 \\
\hline & $\mathbf{N}$ & 106 & 106 \\
\hline \multirow{3}{*}{$\begin{array}{l}\text { Productivity of teachers } \\
\text { (Teacher's performance } \\
\text { appraisal is a fair reflection of } \\
\text { students WASSCE results). }\end{array}$} & Pearson Correlation & $.437^{* *}$ & 1 \\
\hline & Sig. (2-tailed) & .000 & \\
\hline & $\mathbf{N}$ & 106 & 106 \\
\hline
\end{tabular}

From the table above, the two variables appear to be correlated; thus the positive correlation of 0.437 is quite strong and shows that the increase in one variable slightly results in the increase of the other variable. This to say that as teachers are compensated based on their appraisal outcomes, it intends reflect in the performance of students in their final senior high school exams. It must however be noted that, statistically the correlation between two variables is not considered positively significant if it is not above 0.8 hence from our computation above, even though a relationship exists between the variables it is a weak positive relationship which suggest students' performance in WASSCE may not entirely be accounted for by teacher compensations based on their appraisal results.

\subsection{CONCLUSIONS}

The objective of the study was to assess the effects of performance appraisal system on employee productivity with emphasis on teachers in selected public senior high schools in the Ho municipality. The studies specific objectives were to ascertain the various uses of performance appraisal schemes of selected senior high schools in the municipality, assess the relationship between performance appraisal and productivity of teachers as well as to evaluate the extent to which performance appraisal would be used as a tool to increase productivity of teachers in the Ho Municipality. From the literature reviewed, it is realized that for every institution or organization, the performance of the employees is important in achieving organizational goals. The success of every organization can therefore be attributed to performance appraisal. Performance appraisal is one of the basic tools that make workers to be very effective and active at work. A critical assessment of this may reveal the need for motivation, rewards, development, training and good human relationship in an organization thus increasing productivity.

The studies analysis was based upon responses provided by one hundred and six (106) teachers of which 70 were from Ola SHS and 36 from Shia SHTS with the municipality who were simple randomly selected. Also two (2) assistant headmasters were purposively selected to respond to structured interview designed to solicit their expert views on performance appraisal and the productivity of their teachers. With a correlation coefficient of 0.437 a strong positive correlation was established between performance appraisal and teacher productivity with reference to some variables used. Also most respondents disagreed with performance appraisal having anything to do with their compensation and benefits or student performance but however belief that they are promoted based on the number of years served.

\section{REFERENCES}

Abreh, M. K., Owusu, K. A., \& Amedahe, F. K. (2018). Trends in performance of WASSCE candidates in the science and mathematics in Ghana: Perceived contributing factors and the way forward. Journal of Education, 198(1), 113-123.

Alder, R. L. \& Coleman, T. (2000).Performance of Management Profile and Audit of Human Resource Foundation, Society for Human Resource Management Review.

Andre, V. (2013). The knowledge evolution: Expanding organizational intelligence. Routledge.

Anlimachie, M. A. (2012). Understanding the Causes of Students' weak Performance in Geography at the WASSCE and the Implications for School Practices; A Case of Two Senior High Schools in a Rural District of Ghana.

Aquinas, P. G. (2009). Human Resource Management Principles and Practice. New DelhVikas.

Armstrong, M. (2008).A handbook of Human Resource Management Practice (10thed.). London: Kogan Page. Armstrong, M. (2006).Strategic Human Resource Management: A guide to Action, 3 Rd ed. London: Kogan Page. Bateman, T. S. \& Snell, S.A. (1996).Management, Building Competitive Advantage (3rded.).Chicago: Irwin. Best, J. W., \& Kahn, J. V. (1998).Research in education (8th ed.). Boston: Allyn and Bacon. Bhatti KK, Qureshi T.M. (2007). Impact of employee participation on job satisfaction, employee commitment and 
employee productivity. International Review of Business Research, 3(2): 5468.

Bruce, A. (2002). How to Motivate Every Employee. McGraw-Hill Trade, USA

Burney, S. (2012). An Integrated Conceptual Model of Performance Appraisals and Succession Planning using Multi valued Evaluation. Pakistan Journal of Engineering, Technology \& Science, 2(2).

Connolly, T. (1976).Some conceptual and methodological issues in expectancy models of work performance motivation. Academy of Management Review, 1(4): 37-47.

Daley, D. M. (1992). Performance appraisal in the public sector: Techniques and applications. Abc-clio.

DeNisi, A., Cafferty, T., \&Meglino, B. (1984).A cognitive view of the performance appraisal process: A model and some research propositions. Organizational Behavior and Human Decision Processes, 33, 360-396.

Drucker, Peter F. (1974). Management Tasks, Responsibilities, Practices. New York: Harper \& Row Publishers.

Erdogan, B. (2002). Antecedents and Consequences of Justice Perceptions in Performance Appraisals. Human Resource Management Review, 12(4), 555- 578.

Ferris, G. R., Beehr, T. A. \& Gilmore, D. C.(1978).Social facilitation: A review and alternative conceptual model. Academy of Management Review, 3(2), 338-347,

Fisk, C. L. (1995). Lochner Redux: The Renaissance of Laissez-Faire Contract in the Federal Common Law of Employee Benefits. Ohio St. LJ, 56, 153.

Joinson, C. (2001). Making sure employees measure up. HR magazine, 46(3), 36-43.

Khazem, H. A. (2008). Productive performance appraisals. Journal of Applied Management and Entrepreneurship, 13(3), 109.

Lafer, G. (2002). The job training charade. Cornell University Press.

Lansbury, R. (1988). Performance management: A process approach. Asia Pacific Journal of Human Resources, $26(2), 46-54$.

Locke, E. A. (1960). What is job satisfaction?. Organizational behavior and human performance, 4(4), 309-336.

Locke, E., \& Latham, G. (2002). Building a practically useful theory of goal setting and task motivation. American Psychologist, 57, 705-717.

Manasa, K, \& Reddy, N. (2009). Role of Training in Improving Performance. The IUP Journal of Soft Skills, 3 , $72-80$.

Mani, B. G. (2002). Performance appraisal systems, productivity and motivation: A case study. Public Personnel Management, 31(2), 141-159.

Mathis, Robert L. \& Jackson, John H. (2000). Human Resource Management”, (9thed.). Ohio, USA: SouthWestern College Publishing.

Mitchell, T.R. (1982). Motivation: New Directions for Theory, Research, and Practice. The Academy of Management Review,7 (1), 80-88.

Miyamoto, Y. (2007). Organizational Behavior. Milton: John Wiley \& Sons.

Mullins, Laurie J. (1996). Management and Organizational Behavior (4th ed.). London: Pitman Publishing.

Nonaka, I., \& Takeuchi, H. (2011). The wise leader. Harvard business review, 89(5), 58-67.

O'Neil Jr., H.F., \& Drillings, M. (Eds.). (1994). Motivation: Theory and research. Hillsdale, NJ: Lawrence Erlbaum Associates.

Ordóñez, L., Schweitzer, M., Galinsky, A., \& Bazerman, M. (2009). Goals gone wild: The systematic side effects of over prescribing goal setting. Training and Development Journal, 42(7), 30-45.

Pettijohn, L. S., Parker, R. S., Pettijohn, C. E., \& Kent, J. L. (2001). Performance

Appraisals: Usage, criteria and observations. Journal of Management Development, 20(9), 754-773.

Prasetya, A., \& Kato, M. (2010). Correlation among corporate productivity, performance assessment system and salary system (a numerical representation of a qualitative survey). Research Journal of International Studies, 16.

Quick, T. W. (1988). U.S. Patent No. 4,760,096. Washington, DC: U.S. Patent and Trademark Office.

Silberman, L.J., 2003. The impact of jurisdictional rules and recognition practice on international business transactions: the US Regime. Hous. J. Int'l L., 26, p.327.

Simmons, J. (2002). An expert witness: Perspective on performance appraisal in Universities and colleges. Employee Relations, 24(1), 86-100.

Simons, D. J., \& Chabris, C. F. (1999). Gorillas in our midst: sustained in attentional blindness for dynamic events. Perception, 28(9), 1059-1074.

Sink, D. S. (1984).Productivity Management: Planning, Measurement and Evaluation, Control, and Improvement. N.Y: John Wiley.

Smith, K.G., \&Hitt, M.A. (2005).Great minds in management: the process of theory development. New York, NY: Oxford University Press.

Suprihanto, J. (1986). Penilaian Pelaksanaan Pekerjaandan Pengembangan Karyawan. BPFE, Yogyakarta.

Sweiby, K. E. (1986). Knowledge management-Lessons from the pioneers. Retrieved July, 4, 1986.

Vroom, V. (1964). Work and motivation. New York, N.Y: Wiley. 
Walsh, K and Fisher, D. (2005). Action inquiry and performance appraisals. The Learning Organisation, 12 (1), 26-41.

Weber, P. J., Da Silva, L. B., \& Rubenchik, A. M. (2003). U.S. Patent No. 6,524,250. Washington, DC: U.S.

Patent and Trademark Office.

Wiese, D and Buckley, R. (1998).'The evolution of the performance appraisal process. Journal of Management History, 4(3).

Young, K. S. (1996). Psychology of computer use: XL. Addictive use of the Internet: a case that breaks the stereotype. Psychological reports, 79(3), 899-902. 